\title{
Phytochemical Components of Some Minor Cereals Associated with Diabetes Prevention and Management
}

\author{
Rabia Begum Panhwar'1, Ali Akbar', Muhammad Faizer Ali², Qinghua Yang1, Baili Feng1* \\ ${ }^{1}$ State Key Laboratory of Crop Stress Biology in Arid Areas/Northwest A\&F University, Yangling, China \\ ${ }^{2}$ Environmental Engineering \& Management, Mehran University of Engineering \& Technology, Jamshoro, Pakistan \\ Email: Rabiapanhwar@yahoo.com, aliakbarqau@yahoo.com,fyzer_ali@yahoo.com, 1661650143@qq.com, \\ ^fengbaili@nwsuaf.edu.cn
}

How to cite this paper: Panhwar, R.B., Akbar, A., Ali, M.F., Yang, Q.H. and Feng, B.L. (2018) Phytochemical Components of Some Minor Cereals Associated with Diabetes Prevention and Management. Journal of Biosciences and Medicines, 6, 9-22. https://doi.org/10.4236/jbm.2018.62002

Received: January 12, 2018

Accepted: February 10, 2018

Published: February 13, 2018

Copyright $\odot 2018$ by authors and Scientific Research Publishing Inc. This work is licensed under the Creative Commons Attribution International License (CC BY 4.0).

http://creativecommons.org/licenses/by/4.0/

\begin{abstract}
Diabetes is a metabolic disorder by a chronic hyperglycemic condition because of defects in insulin secretion and insulin action or both. Minor cereals are often drought tolerant and fertilizer efficient. In this review we focus the content and bioavailability of phytochemicals in some minor cereals on the basis evidence for increasing plasma phytochemical concentrations and reducing oxidative stress as well as inflammation in humans. Phenolics and Flavanoids are major phytochemicals and may be available with high concentration in minor cereals but as tightly attached with cell wall, their bioavailability is mostly limited. Clinical trials concluded that vitamin $\mathrm{E}$ and other common antioxidants were not helpful for managing diabetic complications. Vicious cycles can cause type $1 \mathrm{DM}$, where as hypoglycemia can forward to down and regulate neuroendocrine. Increased phytochemical bioavailability may be achieved through bio processing of grains but the improvements might be small and have not yet led to changes in clinical associated with reduced risk of T2D. Furthermore, the effects of minor cereals against oxidative stress in healthy individuals can be very low or not occurred but systemic inflammation can be reduced in people after huge intake. More than 300 Indian medicinal plants have antidiabetic property but exact mechanisms for hypoglycemic action of many plants are still unknown. Further studies are required to pay attention toward direct role of minor cereal phytochemicals on alarming diseases diabetes.
\end{abstract}

\section{Keywords}

Minor Cereal, Phytochemical, Diabetes, Hypoglycemia Cycle, Prevention 


\section{Introduction}

Diabetes mellitus (DM) and type 2 diabetes (T2D) both are current health problems which affect millions of individuals worldwide and increase dangerously, but among the total population of diabetic patients more than $90 \%$ suffer from Type 2 Diabetes (T2D). Death and disability, due to type- 2 diabetes are increasing day by day [1] [2] [3]. The cause of Diabetes mellitus (DM) is metabolic disorder of multiple physiology by chronic hyperglycemia with disturbances of carbohydrate, fat and protein metabolism consequently defects in insulin secretion and insulin action, or both. "Type 2 diabetes" can be caused by different factors also includes both genetic as well as environmental factors that affect $\beta$-cell function and tissue of pancreas, muscles and liver [4].

Minor cereals including oat (Avena sativa L.), barley (Hordeumvulgare L.) and common millet (Panicummiliaceum L.) have contributed greatly to agriculture [5]. Recently, cultivation of minor cereals has been increasing because of drought resistant, fertilizer efficient, environment friendly and can cultivate under high temperature conditions [6]. Phytochemicals are the bioactive compound of plants having many biological properties such as antioxidant, anti-inflammatory, antidiabetic, anticancer, modulation of detoxification enzymes, stimulation of the immune system and others [7]. Mostly phytochemicals functions as a antioxidants in vitro and have the potential to moderate oxidative stress and inflammation which can cause pathogenesis of T2D [8]. Consumption of cereals and balanced dietary patterns have been shown to lower risk of diabetes and better results for diabetes individuals. By the changing life style and intake can overcome this diseases and more effective than different huge medicines. Minor cereals intake can reduce the risk of T2D [9] [10] [11].

Various studies demonstrated that frequent intake of minor cereal foods improves metabolic homeostasis and delays or prevents the development of T2D and its complications in a variety of associates, but in mostly of European pedigree [12]-[18]. If minor cereals food added in daily serves about 2 to 3 times then it can reduced the risk of T2D about $20 \%-30 \%$ as compared to 1 serve in whole week. There are many different experimental studies provide evidences between minor cereal intake and diabetes prevention [15] [18].

In addition, minor cereal foods can improve the index of diabetes risk, including glycemic control, fasting plasma insulin, glucose, and insulin sensitivity, as well as include in the management of those individuals with or at high risk of developing T2D [13] [19] [20] [21]. One of the primary pathogenic factors is oxidative stress which leading to insulin resistance, $\beta$-cell dysfunction, impaired glucose tolerance and ultimately T2D [22] [23]. Moreover, a study of human clinical trials concluded that vitamin $\mathrm{E}$ and other common antioxidants were not helpful for managing diabetic complications. But cereal fiber can play important role to reduce the diabetes risk associated with minor cereal consumption [24]. 


\subsection{Phytochemical Component of Some Minor Cereals}

\section{Barley}

Epidemiological studies have proved that regular consumption of barley can reduces the risk of developing chronic diseases and can prevent common nutrition related diseases including diabetes and obesity because of $\beta$-glucan in barley fiber. The phytochemicals of barley have antioxidant, antiproliferative, and cholesterol lowering abilities, which can reduce the risk of certain diseases [25] [26] [27]. Phenolics, tocols and folate are the major phytochemicals of barley [25]. Recently a new variety of barley has developed that has a wide range of nutritional and health benefits [28] [29]. Sterols and tocols are major components of plant oils that can provide benefits like protection against toxins, neurological diseases such as Alzheimer's disease and diabetes [30] [31]. Barley has unique phytochemical properties like the presence of all eight tocolvitamers which are mostly not complete in some other cereals [32]. Some phytochemicals of barley have different constituents as shown in Table 1.

\section{Rye}

Rye has more alkylresorcinols than the other major cereal varieties. The concentration of alkylresorcinol in rye is depending on the high level of folate in the grain. Some varieties of rye also have very high levels of total phenolics but the free phenolics content are very low. Other phytochemicals, such astocols, polyphenols and ferulic acid are also found at low levels in rye [33]. Researcher and reviewers focused on phytochemicals of oat and barley mostly but did not explain rye very well and data is not enough to include in this review article.

\section{Oats}

Tocopherols and tocotrienols, phenolic acids, sterols, selenium and avenanthramides are the major phytochemicals of oats [34]. To differ greatly (5 to 48 $\mu \mathrm{g} / \mathrm{g}$ ) as compare to rice and rye (4 to $9 \mu \mathrm{g} / \mathrm{g}$ ) and also to the higher levels present in wheat and barley ( 23 to $80 \mu \mathrm{g} / \mathrm{g}$ ). The range in the total phenolic levels of oats is also similar to those in wheat and rye, but oats have up to 10-fold higher levels of free and conjugated phenolics. Other phytochemicals, including folate, polyphenols, ferulic acid and flavonoids are found at low levels in oats. Some phytochemicals of oat have different components as shown in Table 1.

Phytochemicals constituents availability in minor cereals (oat and barley) Develaraja S, et al. (2016) [35].

\subsection{Type I and Type II Diabetes}

Diabetes is a metabolic disorder by a chronic hyperglycemic condition because of defects in insulin secretion and insulin action or both [36] [37]. The incidence of diabetes is increasing rapidly worldwide and WHO \& International Diabetes Federation. [38] predicted that the number of adult diabetes can be double in the coming time as from 177 million in 2000 to 370 million in 2030 [39]. During Type I disease different pathogenic processes can be happens from autoimmune destruction of pancreatic $\beta$-cell proteins to create complete insulin deficiency 
Table 1. Some minor cereal and their approximate phytochemical constituents.

\begin{tabular}{|c|c|c|}
\hline Common Names & Barley & Oat \\
\hline Scientific Name & Hordeum vulgare $\mathrm{L}$. & Avena sativa $\mathrm{L}$. \\
\hline Energy (kJ/100gm) & 1481 & 1628 \\
\hline Protein (gm/100gm) & 12.48 & 16.89 \\
\hline Fat $(\mathrm{gm} / 100 \mathrm{gm})$ & 2.3 & 6.9 \\
\hline Carbohydrates (gm/100gm) & 73.48 & 66.27 \\
\hline Fiber (gm/100gm) & 17.3 & 10.6 \\
\hline Calcium (mg/100gm) & 33 & 54 \\
\hline Iron $(\mathrm{mg} / 100 \mathrm{gm})$ & 3.6 & 4.72 \\
\hline Magnisium (mg/100gm) & 133 & 177 \\
\hline Phosphorus (mg/100gm) & 264 & 523 \\
\hline Potassium (mg/100gm) & 452 & 429 \\
\hline Sodium (mg/100gm) & 12 & 2 \\
\hline Zinc (mg/100gm) & 2.77 & 3.97 \\
\hline Selenium (mg/100gm) & 37.7 & ${ }^{*} \mathrm{NR}$ \\
\hline Thaimin (mg/100gm) & 0.646 & 0.763 \\
\hline Ribiflavin (mg/100gm) & 0.285 & 0.139 \\
\hline Niacin (mg/100gm) & 4.604 & 0.961 \\
\hline Folate, total (mcg/100gm) & 19 & 56 \\
\hline beta-Carotene & 13 & ${ }^{*} \mathrm{NR}$ \\
\hline alpha-Carotene & 0 & ${ }^{*} \mathrm{NR}$ \\
\hline Vitamin A (IU) & 22 & 0 \\
\hline
\end{tabular}

${ }^{*}$ NR. Not rated.

whereas in Type II, the multiple abnormalities in which include a combination of genetic factors concerned with impaired insulin secretion, insulin resistance as well as environmental factors such as obesity, overweight, lack of exercise and stress, as well as aging [40]. Whole grain foods and legumes are useful for prevention and management of diabetes [16]. From different observation and various studies on T2D treatment, it is concluded that Pharmacological interference has undesirable side effects but plants and herbal therapy can play important role to overcome or control this serious diseases [7]. Phytochemicals such as catechin, ellagic acid, eugenol, kaempferol, berberin have a unique antidiabetic activity [41]. About $5 \%$ world population affected of diabetes but unfortunately modern medical world can not solve this problem without side effects [7]. When the grain structure has been disrupted than the postprandial glycaemic response to grains having whole structure would show to be lower (Table 2). While grain structure is the most probably give explanation for the measured differences in glycaemic response, different preparation methods and cooking for example boiling compared with baking might also have had an effect. The size of grains 
Table 2. Glycaemic index of grains comparison with disrupted and intact structures.

\begin{tabular}{cccccc}
\hline Reference & Study subjects & Disrupted structure & GI $^{\mathrm{a}}$ & Intact structure & GI \\
\hline Jenkins et al. [1986] [43] & Diabetics (n = 14) & Whole meal rye bread & $89 \pm 76$ & Rye kernels & $47 \pm 5^{*}$ \\
Jenkins et al. [1988] [44] & Diabetics (n 1/4 6-8) & Barley flour bread & $96(6)$ & $75 \%$ barley kernel bread & $39(7)^{*}$ \\
Liljeberg et al. [1992] [45] & Non-diabetics & 80\% Wholemeal barley flour bread & 94.9715 .1 & $80 \%$ barley kernel bread & 57.1710 .3 \\
Granfeldt et al. [1994] [46] & Non-diabetics (n 1/4 9-10) & Barley flour porridge & $6579^{* *}$ & Barley kernels & $3578^{*}$ \\
Granfeldt et al. [1995] [46] & Non-diabetics (n 1/4 9) & Rolled oat porridge & 9377 & Oat kernel porridge & $6077^{*}$ \\
\hline
\end{tabular}

$\mathrm{GI}^{\mathrm{a}}$ with reference to white wheat bread (GI $1 / 4$ 100); mean7s.d., mean (s.e.). ${ }^{\star}$ Significantly different from GI of food with disrupted structure. **Significantly different from white wheat bread. Jenkins et al., (2002) [42]. Researcher did not describe P value in articles.

or their products would show to have a complex relationship with digestion and absorption. During 3 months of study Jenkins observed that just fiber cannot work well because foods has additional fibre and cereal fibre alone into the diet of people with T2DM for 3 months did not improve glycaemic control [42].

\subsection{Hypoglycemia Cycle}

Hyperglycemia starts obvious excessive excretion of urine (polyuria), thirst (polydipsia), constant hunger (polyphagia), weight loss, vision changes and fatigue mostly in type 1 diabetics [47] (WHO.2015). Chronic hyperglycemia can cause microvascular, macrovascular complications, foot ulcers, renal failure, Charcot joints and disturbances in metabolism [36] [48] [49]. Different studies have explained the role played by antecedent hypoglycemia in producing blunted glucose counter regulatory responses during hypoglycemia. Vicious cycles can cause type $1 \mathrm{DM}$, where as hypoglycemia or exercise can feed forward to down regulate neuroendocrine and therefore creating further hypoglycemia (Figure 1). Exercise can manage diabetes as it aids in glycemic control, weight control, reducing blood pressure and improving life style of patients. Unfortunately, the complexity and difficulties of regulating exogenous insulin in a physiologic manner during different physical activities mostly can cause in hypoglycemia with type 1 diabetes mellitus [50]. Hypoglycemia cycle shown in Figure 1.

\subsection{Phytochemicals in Some Minor Cereals}

Minor cereals mostly contain diverse combinations of phytochemicals depending on the type of cereal, location within the grain and grain processed. The outer structures of grains, in specific the pericarp seed coat and aleurone layers, contain much higher levels of phytochemicals i.e. phenolic compounds, phytosterols, tocols, betaine and folate, than the germand endosperm [51]. Phenolic compounds are the very different and complex class of phytochemicals in cereal grains [52] [53]. They consist of several derivatives of benzoic and cinnamic acids as well as flavonoids, flavones and flavanols, anthocyanidins, avenanthramides, lignans and alkylresorcinols. In most grains phenolic acids are concentrated in the bran and embryo cell walls and exist mostly in an insoluble bound form, free and soluble-conjugated forms being minor bodies [54] [55]. The 


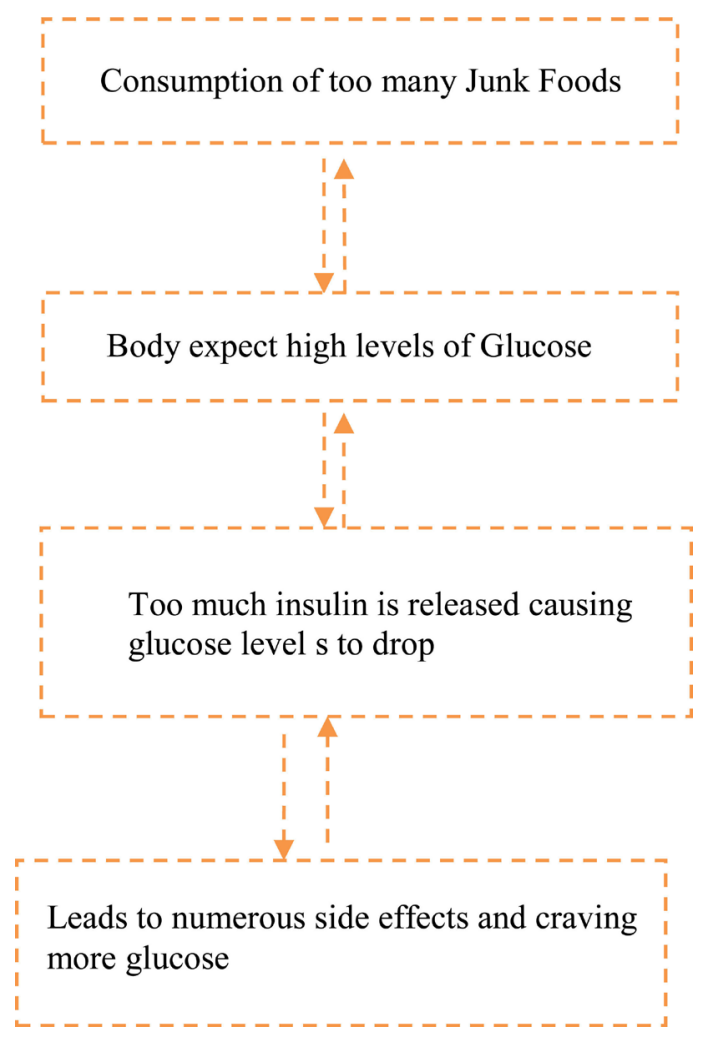

Figure 1. Hypoglycemia cycle.

phenolic acid content of minor cereals is believed as main donor to total antioxidant capacity [54]. Other main phytochemicals that occur in minor cereals which may have a role in protecting against diabetes include a variety of carotenoids, particularly $\alpha$ - and $\beta$-carotene, lutein, $\beta$-cryptoxanthin and zeaxanthin, all of which are located mostly in the bran and germ fractions [53] Some having provitamin A activity, they all function as antioxidants. Other phytochemicals with strong antioxidant capacities comprise phytate (which chelates prooxidant minerals) and a variety of terpenes and terpenoids (phytosterols and tocols).

If Grains are processed by different method containing milling, grinding and flaking, which make taste and edible grains but these treatments may decreased content of phytochemicals and their bioavailability is increased [56]. Thermal and bioprocessing both can make better phytochemical bioavailability, particularly the latter method, even if the results are not always reliable. Differences among some minor cereals in their contents of different micronutrients and phytochemicals are shown in Table 3.

\subsection{Metabolic Disease and Prevention Role by Minor Cereals}

Diabetes mellitus (DM) can cause by hyperglycemia and metabolic disorder of insulin secretary response [7]. Recently, Type-2 diabetes (T2D) is a big health problem around the world and the incidences are increasing day by day. According to some predictions TD2 can rise from 366 million people to 552 million in the next two decades [1] [57]. It can cause of serious death and disability but 
Table 3. Phytochemicals in some minor cereals.

\begin{tabular}{|c|c|c|c|}
\hline Phytochemicals & Barley & Oat & Rye \\
\hline Methionine $(\mathrm{g} / 100 \mathrm{~g})$ & $0.03-0.08$ & 0.18 & 0.18 \\
\hline Cystine (g/100g) & 0.060 .2 & 0.18 & 0.18 \\
\hline Selenium $(\mathrm{mg} / 100 \mathrm{~g})$ & $0.002-0.030$ & $<0.10-3.3$ & 0.00014 \\
\hline Folate $(\mathrm{mg} / 100 \mathrm{~g})$ & $0.5-0.8$ & $0.05-0.06$ & $0.55-0.80$ \\
\hline Choline $(\mathrm{mg} / 100 \mathrm{~g})$ & $6.9-11$ & $2.0-2.6$ & Unknown \\
\hline Tocopherols + tocotrienols & $4.7-6.8$ & $0.05-4.8$ & $0.4-0.7$ \\
\hline Carotenoids(total) (mg gallic acid eq./100g) & $0.015-0.105$ & 0.031 & Unknown \\
\hline Polyphenols(mg/100g) & $50-196$ & $9-34$ & $125-255$ \\
\hline $\begin{array}{c}\text { Phenolic acids }(\mu \mathrm{g} / \mathrm{g}) \\
\text { Dry weight }\end{array}$ & $100-550$ & $350-874$ & $200-1080$ \\
\hline Ferulic acid (total, mg/100g) & $110-120$ & $2.1-2.4$ & $3.9-5.0$ \\
\hline Flavanoids (total, mg/100g) & $12-18$ & $5.6-8.2$ & $6.7-7.5$ \\
\hline \multicolumn{4}{|l|}{ Other $(\mathrm{mg} / 100 \mathrm{~g})$} \\
\hline Alkylresorcinols $(\mu \mathrm{g} / \mathrm{g})$ & $0-150$ & Not present & $570-3220$ \\
\hline Avenanthramides $(\mathrm{mg} / 100 \mathrm{~g})$ & Not present & $4.9-27.5$ & Not present \\
\hline Betaine (mg/100g) & $40-76$ & $11.3-100$ & Unknown \\
\hline Phytosterols (mg/100g) & $90-115$ & Unknown & Unknown \\
\hline
\end{tabular}

Damien P Belobrajdic and Anthony R Bird (2013) [8]. Different phytochemicals showed different ratio in oat, barly and Rye.

regular exercise and balance food can overcome this disease than pharmacological interventions. The start and carry of T2D regulated by a complex inter play of multiple lifestyle and heredity chronic metabolic disorders [1] [3] [11]. The decline in $\beta$-cell function can create abnormal insulin gene during glucotoxic state and reduce insulin secretion also. Herbal drugs are widely used because of their effectiveness, less side effects and relatively cheap in cost [58]. More than 300 Indian medicinal plants have antidiabetic property but exact mechanism for hypoglycemic action of many plants are still unknown [7]. Phytochemical supplementation will be needed in additional for cardiovascular disease [59]. Different plant derived flavonoids and their common antioxidant activity have been reported to slow down aldose reductase activity and impart beneficial action in diabetic complications (Figure 2).

The difference of generation and scavenging of free radicals play specific role in determining tissue damage related with diabetes. There is a hypothesis that if influx of FFAs (free fatty acids) raised into pancreatic $\beta$-cell through lipotoxicity mechanism can cause to the loss of their secretory ability and specific sign of type 2 diabetes [60].

\subsection{Bioavailability of Minor Cereal Phytochemical}

Bioavailability means to take fraction of phytochemical or other food materials 


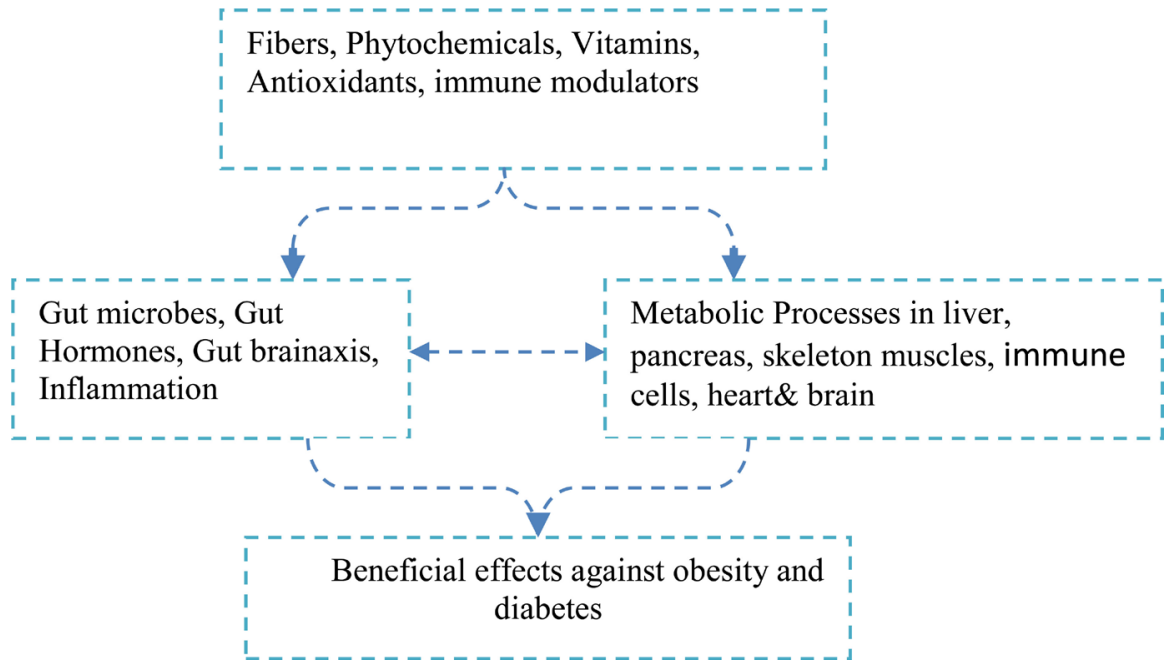

Figure 2. Beneficial minor cereals ingredient against metabolic diseases.

which circulates and reaches at digestive system. Tracer methods present accurately determining bioavailability in which atoms or molecules of the phytochemical within the grain are labelled with an intrinsic radioactive or stable marker but this technique has not been used to measure bioavailability of phytochemicals in cereals. Mostly indirect measures are very common, for example, the balance method (intake minus fecal output), incremental area under the postprandial serum concentration curve and incremental urinary excretion. Many in vitro methods have also been published but not sufficient to understand. Bioavailability of phytochemicals types is quite different from one another. Folate and $\alpha$-tocopherol are quickly absorbed from the small intestine and their bioavailability is free from dietary fibre content (Table 4). Mostly polyphenols are tightly bound to cell walls within the grain matrix thus their bioavailability is limited in the upper gut [61]. If polyphenols even are released from the grain matrix during digestion but they may not be absorbed in the small intestine as they are very hydrophilic to cross the epithelium by passive diffusion [62]. The evidence for minor cereals rich diets improving blood is based on antioxidant defense is during modulation of the glutathione radical scavenging system. This system consumes glutathione peroxidase to metabolise hydrogen peroxide to water by via reduced glutathione as a hydrogen donor [63]. Another supporting evidence is a reduction in pro-inflammatory markers in human intaking higher levels of minor cereals fibre. For example, cereal fibre intakes, although not total fibre were connected with significantly lower plasma cytokine levels in healthy adults [64]. Minor cereals have bioactive phytoconstituents i.e. fibers, alkaloids, flavonoids, saponins and other phytochemicals, vitamins, antioxidants and immune modulators with some known health benefits against obesity and diabetes. These bioactive phytochemicals, both in isolation and in combination play important role for improvement of glucose metabolism in different metabolic organs such as liver, pancreas, skeletal muscles, adipose tissue, gastrointestinal tract, immune cells and brain directly or indirectly through effect on gut microbiome, 
Table 4. Minor cereal phytochemicals, factors affecting their bioavailability and suggested mechanisms for promoting health.

\begin{tabular}{|c|c|c|c|c|}
\hline Phytochemical & $\begin{array}{l}\text { Minor cereal } \\
\text { Sources }\end{array}$ & $\begin{array}{l}\text { Food \& dietary factors } \\
\text { affecting bioavailability }\end{array}$ & $\begin{array}{l}\text { Other factors that } \\
\text { Enhance bioavailability }\end{array}$ & Potential mechanisms of action \\
\hline \multicolumn{5}{|l|}{ Phenolics } \\
\hline \multirow[t]{2}{*}{ Free } & \multirow[t]{2}{*}{ Oats } & \multirow[t]{2}{*}{ Milk Heme iron } & Unknown & $\begin{array}{l}\text { Increase plasma total antioxidant capacity to directly } \\
\text { mitigate oxidative stress }\end{array}$ \\
\hline & & & Unknown & Indirect through cell signaling \\
\hline \multirow{2}{*}{ Bound } & \multirow{2}{*}{$\begin{array}{l}\text { barley, } \\
\text { oats, rye }\end{array}$} & \multirow{2}{*}{ Grain structure } & Bioprocessing of grain & $\begin{array}{l}\text { Increase plasma total antioxidant capacity to directly } \\
\text { mitigate oxidative stress }\end{array}$ \\
\hline & & & $\begin{array}{l}\text { Colonic fermentation } \\
\text { (limited evidence) }\end{array}$ & Indirect through cell signaling \\
\hline Flavanoids & Barley & $\begin{array}{l}\text { Grain } \\
\text { structure }\end{array}$ & Unknown & $\begin{array}{l}\text { Increase plasma uric acid levels which has reducing } \\
\text { and free radical scavenging activities } \\
\text { Improve glutathione radical scavenging system }\end{array}$ \\
\hline Selenium & barley oats rye & $\begin{array}{l}\text { Not relevant as } \\
\text { readily available }\end{array}$ & $\begin{array}{l}\text { Not relevant as readily } \\
\text { available }\end{array}$ & $\begin{array}{l}\text { A cofactor for glutathione peroxidase, an enzyme that } \\
\text { quenches reactive oxygen species }\end{array}$ \\
\hline
\end{tabular}

Damien P Belobrajdic and Anthony R Bird, (2013) [8].

gut hormones, gut-brain axis, inflammatory response, oxidative stress and cholesterol profiles as well.

\section{Conclusions}

In conclusion, diabetes is a very serious disease but $\mathrm{T} 2 \mathrm{D}$ is more dangerous than DM because T2D can cause serious morbidity, disability and mortality in humans, however Hyperglycemia, abnormal lipid metabolism and antioxidant stress are the most common complications in diabetes mellitus.

Minor cereals are sustainable crop as well as environment friendly and their phytochemicals have many useful biological properties against diabetes and other diseases but unfortunately the researches and reviews to focus these unique properties are still negligible. Medical world still can not solve this problem without any side effects. Diabetic patients are taking pharmaceutical drugs to get relief from diabetes complications but side effects creating other problems so in this critical situation, modern science should focus on natural things benefits.

Nowadays researcher getting interest toward colonic micro biota and bio processing used for phytochemical bioavailability but unfortunately it's very limited and insufficient to reduce the risk of diabetes. More studies are required to investigate the direct role of minor cereal phytochemicals and diabetes.

\section{Acknowledgements}

This work was supported by the National Natural Science Foundation of China (31371529), National Millet Crops Research and Development System (CARS-07), National Science and Technology Supporting Plan (2014BAD07B03), and Minor Grain Crops Research and Development System of Shaanxi Province (2014-2017). 


\section{References}

[1] Whiting, D.R., Guariguata, L., Weil, C. and Shaw, J. (2011) Diabetes Atlas: Global Estimates of the Prevalence of Diabetes for 2011 and 2030. Diabetes Research and Clinical Practice, 94, 311-321.

[2] Misra, A., Singhal, N. and Khurana, L. (2010) Obesity, the Metabolic Syndrome, and Type 2 Diabetes in Developing Countries: Role of Dietary Fats and Oils. Journal of the American College of Nutrition, 29, 289S-301S.

[3] Fitzgerald, M.A., Rahman, S., Resurreccion, A.P., Concepcion, J., Daygon, V.D., Dipti, S.S., Kabir, K.A., Klingner, B., Morell, M. and Bird, A. (2011) Identification of a Major Genetic Determinant of Glycaemic Index in Rice. Rice, 4, 66-74.

[4] Wang, T., Shankar, K., Ronis, M.J. and Mehendale, H.M. (2007) Mechanisms and Outcomes of Drug- and Toxicant-Induced Liver Toxicity in Diabetes. Critical Reviews in Toxicology, 37, 413-459.

[5] Diao, X.M. (2017) Production and Genetic Improvement of Minor Cereals in China. The Crop Journal, 5, 103-114.

[6] Diao, X.M. and Jia, G.Q. (2016) Origin and Domestication of Foxtail Millet. Genetics and Genomics of Setaria, 61-72.

[7] Mishra, C., Singh, B., Singh, S., Siddiqui, M.J.A. and Mahdi, A.A. (2015) Role of Phytochemicals in Diabeties Lipotoxicity: An Review. International Journal of Research and Development in Pharmacy and Life Sciences, 4, 1604-1610.

[8] Belobrajdic, D.P. and Bird, A.R. (2013) The Potential Role of Phytochemicals in Wholegrain Cereals for the Prevention of Type-2 Diabetes. Belobrajdic and Bird Nutrition Journal, 12, 62.

[9] Hodge, A.M., English, D.R., O’Dea, K. and Giles, G.G. (2007) Dietary Patterns and Diabetes Incidence in the Melbourne Collaborative Cohort Study. American Journal of Epidemiology, 165, 603-610.

[10] Brunner, E.J., Mosdol, A., Witte, D.R., Martikainen, P., Stafford, M., Shipley, M.J. and Marmot, M.G. (2008) Dietary Patterns and 15-y Risks of Major Coronary Events, Diabetes, and Mortality. American Journal of Clinical Nutrition, 87, 1414-1421.

[11] Nettleton, J.A., McKeown, N.M., Kanoni, S., Lemaitre, R.N., Hivert, M.F., Ngwa, J., van Rooij, F.J., Sonestedt, E., Wojczynski, M.K. and Ye, Z. (2010) Interactions of Dietary Whole-Grain Intake with Fasting Glucose-and Insulin-Related Genetic Loci in Individuals of European Descent: A Meta-Analysis of 14 Cohort Studies. Diabetes Care, 33, 2684-2691. https://doi.org/10.2337/dc10-1150

[12] McKeown, N.M., Meigs, J.B., Liu, S., Wilson, P.W. and Jacques, P.F. (2002) Whole-Grain Intake Is Favorably Associated with Metabolic Risk Factors for Type 2 Diabetes and Cardiovascular Disease in the Framingham Offspring Study. The American Journal of Clinical Nutrition, 76, 390-398. https://doi.org/10.1093/ajcn/76.2.390

[13] Pereira, M.A., Jacobs Jr., D.R., Pins, J.J., Raatz, S.K., Gross, M.D., Slavin, J.L. and Seaquist, E.R. (2002) Effect of Whole Grains on Insulin Sensitivity in Overweight Hyperinsulinemic Adults. The American Journal of Clinical Nutrition, 75, 848-855. https://doi.org/10.1093/ajcn/75.5.848

[14] van Dam, R.M., Rimm, E.B., Willett, W.C., Stampfer, M.J. and Hu, F.B. (2002) Dietary Patterns and Risk for Type 2 Diabetes Mellitus in U.S. Men. Annals of Internal Medicine, 136, 201-209. https://doi.org/10.7326/0003-4819-136-3-200202050-00008

[15] Murtaugh, M.A., Jacobs Jr., D.R., Jacob, B., Steffen, L.M. and Marquart, L. (2003) Epidemiological Support for the Protection of Whole Grains against Diabetes. Pro- 
ceedings of the Nutrition Society, 62, 143-149. https://doi.org/10.1079/PNS2002223

[16] Venn, B.J. and Mann, J.I. (2004) Cereal Grains, Legumes and Diabetes. European Journal of Clinical Nutrition, 58, 1443-1461. https://doi.org/10.1038/sj.ejcn.1601995

[17] de Munter, J.S., Hu, F.B., Spiegelman, D., Franz, M. and van Dam, R.M. (2007) Whole Grain, Bran, and Germ Intake and Risk of Type 2 Diabetes: A Prospective Cohort Study and Systematic Review. PLoS Medicine, 4, 261. https://doi.org/10.1371/journal.pmed.0040261

[18] Priebe, M.G., van Binsbergen, J.J., de Vos, R. and Vonk, R.J. (2008) Whole Grain Foods for the Prevention of Type 2 Diabetes Mellitus. The Cochrane Database of Systematic Reviews, 23, CD006061. https://doi.org/10.1002/14651858.CD006061.pub2

[19] Jang, Y., Lee, J.H., Kim, O.Y., Park, H.Y. and Lee, S.Y. (2001) Consumption of Whole Grain and Legume Powder Reduces Insulin Demand, Lipid Peroxidation, and Plasma Homocysteine Concentrations in Patients with Coronary Artery Disease: Randomized Controlled Clinical Trial. Arteriosclerosis, Thrombosis, and Vascular Biology, 21, 2065-2071. https://doi.org/10.1161/hq1201.100258

[20] Lutsey, P.L., Jacobs Jr., D.R., Kori, S., Mayer-Davis, E., Shea, S., Steffen, L.M., Szklo, M. and Tracy, R. (2007) Whole Grain Intake and Its Cross-Sectional Association with Obesity, Insulin Resistance, Inflammation, Diabetes and Subclinical CVD: The MESA Study. British Journal of Nutrition, 98, 397-405. https://doi.org/10.1017/S0007114507700715

[21] Rave, K., Roggen, K., Dellweg, S., Heise, T., tom Dieck, H. (2007) Improvement of Insulin Resistance after Diet with a Whole-Grain Based Dietary Product: Results of a Randomized, Controlled Cross-Over Study in Obese Subjects with Elevated Fasting Blood Glucose. British Journal of Nutrition, 98, 929-936. https://doi.org/10.1017/S0007114507749267

[22] Ceriello, A. and Motz, E. (2004) Is Oxidative Stress the Pathogenic Mechanism Underlying Insulin Resistance, Diabetes, and Cardiovascular Disease? The Common Soil Hypothesis Revisited. Arteriosclerosis, Thrombosis, and Vascular Biology, 24, 816-823. https://doi.org/10.1161/01.ATV.0000122852.22604.78

[23] Robertson, R.P. (2004) Chronic Oxidative Stress as a Central Mechanism for Glucose Toxicity in Pancreatic Islet Beta Cells in Diabetes. The Journal of Biological Chemistry, 279, 42351-42354. https://doi.org/10.1074/jbc.R400019200

[24] Smith, C.E. and Tucker, K.L. (2011) Health Benefits of Cereal Fibre: A Review of Clinical Trials. Nutrition Research Reviews, 15, 1-14.

[25] Idehen, E., Tang, Y. and Sang, S. (2017) Bioactive Phytochemicals in Barley. Journal of Food and Drug Analysis, 25, 148-161. https://doi.org/10.1016/j.jfda.2016.08.002

[26] Adolphe, J. and Fitzpatrick, K. (2014) Barley and Diabetes. Hemoglobin, 1, 6-5.

[27] Benkeblia, N. and Thondre, P.S. (2014) Barley $\beta$-Glucan: Natural Polysaccharide for Managing Diabetes and Cardiovascular Diseases, Polysaccharides: Natural Fibers in Food and Nutrition. CRC Press, Boca Raton, FL, 233-258.

[28] Bird, A.R., Vuaran, M.S., King, R.A., Noakes, M., Keogh, J., Morell, M.K. and Topping, D.L. (2008) Wholegrain Foods Made from a Novel High-Amylose Barley Variety (Himalaya 292) Improve Indices of Bowel Health in Human Subjects. British Journal of Nutrition, 99, 1032-1040. https://doi.org/10.1017/S000711450783902X

[29] King, R.A., Noakes, M., Bird, A.R., Morell, M.K. and Topping, D.L. (2008) An Extruded Cereal Made from a High Amylose Barley Cultivar Has a Low Glycemic Index and Lower Plasma Insulin Response than One Made from a Standard Barley. Journal of Cereal Science, 48, 526-530. https://doi.org/10.1016/j.jcs.2007.11.009 
[30] Bartłomiej, S., Justyna, R.K. and Ewa, N. (2012) Bioactive Compounds in Cereal Grains-Occurrence, Structure, Technological Significance and Nutritional Benefits-A Review. Food Science and Technology International, 18, 559-568. https://doi.org/10.1177/1082013211433079

[31] Shahidi, F. and Zhong, Y. (2010) Lipid Oxidation and Improving the Oxidative Stability. Chemical Society Reviews, 39, 4067-4079. https://doi.org/10.1039/b922183m

[32] Zielinski, H. (2006) Tocotrienols: Distribution and Sources Cereals-Role in Human Health. In: Watson, R.R. and Preedy, V.R., Eds., Tocotrienols. Vitamin E beyond Tocopherols, Vol. 1, CRC Press, Boca Raton, FL, 23-42.

[33] Nystrom, L., Lampi, A.-M., Andersson, A.A.M., Kamal-Eldin, A., Gebruers, K., Courtin, C.M., Delcour, J.A., Li, L., Ward, J.L. and Fras, A. (2008) Phytochemicals and Dietary Fiber Components in Rye Varieties in the HEALTHGRAIN Diversity Screen. Journal of Agricultural and Food Chemistry, 56, 9758-9766. https://doi.org/10.1021/jf801065r

[34] Peterson, D.M. (2001) Oat Antioxidants. Journal of Cereal Science, 33, 115-129. https://doi.org/10.1006/jcrs.2000.0349

[35] Develaraja, S., Reddy, A., Yadav, M., Jain, S. and Hariom, Y. (2016) Whole Grains in Amelioration of Metabolic Derangements. Journal of Nutritional Health \& Food Science, 4, 1-11. https://doi.org/10.15226/jnhfs.2016.00173

[36] Piero, N.M., Kimuni, N.S., Ngeranwa, N.J., Orinda, O.G. and Njagi, M.J. (2015) Antidiabetic and Safety of Lantana rhodesiensis in Alloxan Induced Diabetic Rats. Journal of Developing Drugs, 4, 129. https://doi.org/10.4172/2329-6631.1000129

[37] Piero, M.N., Njagi, J.M., Kibiti, C.M., Ngeranwa, J.J.N. and Njagi, E.N.M. (2012) Metabolic Complications of Diabetes Mellitus: A Review. South Asian Journal of Biological Science, 2, 37-49.

[38] World Health Organization \& International Diabetes Federation (2004) Diabetes Action Now.

[39] Rowley, W.R. and Bezold, C. (2012) Creating Public Awareness: State 2025 Diabetes Forecasts. Population Health Management, 15, 194-200. https://doi.org/10.1089/pop.2011.0053

[40] American Diabetes Association (2012) Diagnosis and Classification of Diabetes Mellitus. Diabetes Care, 35, S64-S71. https://doi.org/10.2337/dc12-s064

[41] Son, M.J., Rico, C.W., Nam, S.H. and Kang, M.Y. (2011) Effect of Oryzanol and Ferulic Acid on the Glucose Metabolism of Mice Fed with a High Fat Diet. Journal of Food Science, 76, 7-10. https://doi.org/10.1111/j.1750-3841.2010.01907.x

[42] Jenkins, D.J., Kendall, C.W., Augustin, L.S., Martini, M.C., Axelsen, M., Faulkner, D., Vidgen, E., Parker, T., Lau, H., Connelly, P.W., Teitel, J., Singer, W., Vandenbroucke, A.C., Leiter, L.A. and Josse, R.G. (2002) Effect of Wheat Bran on Glycemic Control and Risk Factors for Cardiovas-Cular Disease in Type 2 Diabetes. Diabetes Care, 25, 1522-1528. https://doi.org/10.2337/diacare.25.9.1522

[43] Jenkins, D.J., Wolever, T.M., Jenkins, A.L., Giordano, C., Giudici, S., Thompson, L.U., Kalmusky, J., Josse, R.G. and Wong, G.S. (1986) Low Glycemic Response to Traditionally Processed Wheat and Rye Products: Bulgur and Pumpernickel Bread. The American Journal of Clinical Nutrition, 43, 516-520. https://doi.org/10.1093/ajcn/43.4.516

[44] Jenkins, D.J., Wolever, T.M., Buckley, G., Lam, K.Y., Giudici, S., Kalmusky, J., Jenkins, A.L., Patten, R.L., Bird, J. and Wong, G.S. (1988) Low-Glycemic-Index Starchy Foods in the Diabetic Diet. The American Journal of Clinical Nutrition, 48, 248-254. https://doi.org/10.1093/ajcn/48.2.248 
[45] Liljeberg, H., Granfeldt, Y. and Bjorck, I. (1992) Metabolic Responses to Starch in Bread Containing Intact Kernels versus Milled Flour. European Journal of Clinical Nutrition, 46, 561-575.

[46] Granfeldt, Y., Hagander, B. and Bjorck, I. (1995) Metabolic Responses to Starch in Oat and Wheat Products. On the Importance of Food Structure, Incomplete Gelatinization or Presence of Viscous Dietary Fibre. European Journal of Clinical Nutrition, 49, 189-199.

[47] World Health Organization (2015) Diabetes Fact Sheet No. 312.

[48] Basu, S., Berkowitz, S.A. and Seligman, H. (2017) The Monthly Cycle of Hypoglycemia: An Observational Claims-Based Study of Emergency Room Visits, Hospital Admissions, and Costs in a Commercially Insured Population. Medical Care, 55, 639-645.

[49] Kalra, S., Mukherjee, J.J., Venkataraman, S., Bantwal, G., Shaikh, S., Saboo, B., Das, A.K. and Ramachandran, A. (2013) Hypoglycemia: The Neglected Complication. Indian Journal of Endocrinology and Metabolism, 5, 819-834. https://doi.org/10.4103/2230-8210.117219

[50] Ertl, A.C. and Davis, S.N. (2004) Evidence for a Vicious Cycle of Exercise and Hypoglycemia in Type 1 Diabetes Mellitus. Diabetes Metabolism Research and Reviews, 20, 124-130. https://doi.org/10.1002/dmrr.450

[51] Fardet, A., Llorach, R., Orsoni, A., Martin, J.F., Pujos-Guillot, E., Lapierre, C. and Scalbert, A. (2008) Metabolomics Provide New Insight on the Metabolism of Dietary Phytochemicals in Rats. The Journal of Nutrition, 138, 1282-1287. https://doi.org/10.1093/jn/138.7.1282

[52] Okarter, N. and Liu, R.H. (2010) Health Benefits of Whole Grain Phytochemicals. Critical Reviews in Food Science and Nutrition, 50, 193-208. https://doi.org/10.1080/10408390802248734

[53] Adom, K.K., Sorrells, M.E. and Liu, R.H. (2005) Phytochemicals and Antioxidant Activity of Milled Fractions of Different Wheat Varieties. Journal of Agricultural and Food Chemistry, 53, 2297-2306. https://doi.org/10.1021/jf048456d

[54] Jonnalagadda, S.S., Harnack, L., Liu, R.H., McKeown, N., Seal, C., Liu, S. and Fahey, G.C. (2011) Putting the Whole Grain Puzzle Together: Health Benefits Associated with Whole Grains-Summary of American Society for Nutrition 2010 Satellite Symposium. The Journal of Nutrition, 141, 1011S-1022S. https://doi.org/10.3945/jn.110.132944

[55] Fardet, A. (2010) New Hypotheses for the Health-Protective Mechanisms of Whole-Grain Cereals: What Is Beyond Fibre? Nutrition Research Reviews, 23, 65-134. https://doi.org/10.1017/S0954422410000041

[56] Anson, N.M., Aura, A.M., Selinheimo, E., Mattila, I., Poutanen, K., van den Berg, R., Havenaar, R., Bast, A. and Haenen, G.R. (2011) Bioprocessing of Wheat Bran in Whole Wheat Bread Increases the Bioavailability of Phenolic Acids in Men and Exerts Antiinflammatory Effects Ex Vivo. The Journal of Nutrition, 141, 137-143. https://doi.org/10.3945/jn.110.127720

[57] Shaw, J.E., Sicree, R.A. and Zimmet, P.Z. (2010) Global Estimates of the Prevalence of Diabetes for 2010 and 2030. Diabetes Research and Clinical Practice, 87, 4-14. https://doi.org/10.1016/j.diabres.2009.10.007

[58] Venkatesh, S., Reddy, G.D., Reddy, B.M., Ramesh, M. and Appa Rao, A.V.N. (2003) Antihyperglycemic Activity of Caralluma attenuate. Fitoterapia, 74, 274-279. https://doi.org/10.1016/S0367-326X(03)00021-2

[59] Lerman, R., Minich, D., Darland, G., Lamb, J., Chang, J. and Hsi, A. (2010) Subjects 
with Elevated LDL Cholesterol and Metabolic Syndrome Benefit from Supplementation with Soy Protein, Phytosterols, Hops rho Iso-Alpha Acids, and Acacia nilotica Proanthocyanidins. Journal of Clinical Lipidology, 4, 59-68.

https://doi.org/10.1016/j.jacl.2009.11.002

[60] Petersen, K.F. and Shulman, G.I. (2006) Etiology of Insulin Resistance. American Journal of Medicine, 119, 10-16. https://doi.org/10.1016/j.amjmed.2006.01.009

[61] Scholz, S. and Williamson, G. (2007) Interactions Affecting the Bioavailability of Dietary Polyphenols In Vivo. International Journal for Vitamin and Nutrition Research, 77, 224-235. https://doi.org/10.1024/0300-9831.77.3.224

[62] Manach, C., Scalbert, A., Morand, C., Rémésy, C. and Jiménez, L. (2004) Polyphenols: Food Sources and Bioavailability. The American Journal of Clinical Nutrition, 79, 727-747.

[63] Valko, M., Leibfritz, D., Moncola, J., Cronin, M.D., et al. (2007) Free Radicals and Antioxidants in Normal Physiological Functions and Human Disease. The International Journal of Biochemistry \& Cell Biology, 39, 44-84. https://doi.org/10.1016/j.biocel.2006.07.001

[64] Chuang, S.C., Vermeulen, R., Sharabiani, M.T., Sacerdote, C., Fatemeh, S.H., Berrino, F., Krogh, V., Palli, D., Panico, S. and Tumino, R. (2011) The Intake of Grain Fibers Modulates Cytokine Levels in Blood. Biomarkers, 16, 504-510.

https://doi.org/10.3109/1354750X.2011.599042 